\title{
EXPLORING FARMERS' SEASONAL AND FULL YEAR ADOPTION OF STALL FEEDING OF LIVESTOCK IN TIGRAI REGION, ETHIOPIA ${ }^{1}$
}

\author{
Munz Hadush ${ }^{2}$
}

\begin{abstract}
Adoption of stall feeding (SF) of livestock was assessed in northern Ethiopia based on a household survey conducted in 2015. The study covered 21 communities in Tigrai to account for differences in agroecology. The purpose of this study was to understand the driving factors of full or seasonal SF adoption and its intensity. A Heckman selection model was used to estimate adoption and extent of adoption based on a model of technology adoption within an agricultural household framework, and Poisson Model for explaining the number of SF adopting seasons. The descriptive results indicate that $36 \%$ of the farmers were actually practicing $S F$ in a full year whereas $55.6 \%$ were seasonal adopters in the study area.

Empirical results of this study showed that our result is in favor of the Boserupian hypothesis indicating that small grazing land and large exclosure are associated with a higher probability of use of SF and with a higher number of SF adopting seasons. In a similar vein, small average village farm size stimulated SF adoption and adopting seasons, Availability of labor and a number of breed cows significantly increased the probability of using SF by $0.01 \%$ and $66 \%$ respectively. While animal shock had a marginal effect of $14 \%$, factors such as access to information and early exposure increased SF adoption by about $18 \%$ and $6 \%$. Similarly, the positive marginal effect of real milk price is $15 \%$. However, SF appears to be less attractive to those farmers with more herd size and less crop residue.
\end{abstract}

Key words: Adoption and intensity; stall-feeding practice; Heckman model: count model; Ethiopia

JEL: Q1, Q16, Q01.

1 Acknowledgements: This research has been sponsored by the collaborative research and capacitybuilding project on Climate Smart Natural Resource Management and Policy (NORHEDCLISNARP) between Mekelle University and Norwegian University of Life Sciences. The NORHED-CLISNARP project and this research is funded by the Norwegian Agency for Development Cooperation (NORAD) and the Quota Scholarship programme of StatensLånekasse for Utdanning. Special thanks goes to my Supervisor Professor Stein Holden (NMBU), Norway for his unreserved advisorship and Co-advisor, Dr. Mesfin Tilahun (MU) for his assistance.

2 Muuz Hadush, Ph.D. student, Norwegian University of Life Science, Universitetstunet 3, 1430 Ås, Norway, Lecturer at Mekelle University, Department of Economics, Mekelle-Ethiopia, Phone: 251 914732 232, Email: muuz.hadush.gebremichael@nmbu.no, muuz.hadush@mu.edu.et. 


\section{Introduction}

In most sub-Saharan African (SSA) countries, communal grazing lands are important sources of livestock feed (ILRI, 2000).Overstocking is identified to primarily drive degradation of rangelands, declining of vegetation productivity and eventually livestock productivity, and loss of resilience of the rangeland for droughts (Lal and Stewart, 2010). Indeed, overgrazing is reported to cause about half (49\%) of the land degradation in SSA followed by deforestation (27\%) (Kirui et al., 2014). The resource loss due to land degradation in the region is huge (Maitima, 2009). The estimated annual costs of land degradation in Ethiopia is 3\% of agricultural GDP (Yesuf et al.,2008). The role of agricultural technology is widely recognized as a key means of enhancing productivity (Diao and Nin-Pratt, 2007). However, many of these practices have not been widely adopted by the smallholder farmers (Odame et al., 2013).

Animal nutritionists point out that poor animal feed is the leading factors for low livestock productivity. Whereas the veterinary experts argue that poor animal health as the main constraint (Amudavi et al., 2009). Livestock production, in Ethiopia, is low in productivity in terms of milk and meat production per animal (Negassa et al., 2012). For instance, IFAD (2007) showed that inadequate livestock nutrition and poor feeding practices are the main reasons for low animal production. As a result, the average milk production was estimated to be 1.86 liters/cow per day and the per capita milk consumption was about $19.2 \mathrm{Kg} /$ year in Ethiopia (FAO, 2009).

Despite natural grazing lands are deficient in terms of nutrition quality and quantity due to drought, cattle farming is still heavily dependent on free grazing in Ethiopia (USAID, 2013). Benin (2006) indicated that increasing populations result in high demand for arable land for food production and settlement for humans, reducing the size of land available for natural grazing. An exclosure is also responsible for shrinking grazing land and grass production (Mekuria et al., 2011) despite the fact that it can provide economic and ecological benefits (Babulo et al.,2009). In addition to feed and water shortage, animal diseases due to free grazing, poor input supply, low technology use and poor marketing have been cited as extra factors constraining livestock performance (Yilma et al., 2011; Gebremedhin et al., 2009).

Improving feed qualities through the use of new technologies such as forage, rotational and stall feeding $(\mathrm{SF})^{3}$ are suggested as not only economically viable (Garcia et al.,2008; Lenaerts, 2013; Beshir, 2014) but also ecologically sustainable in mitigating feed shortages. Besides, Baltenweck et al.(2007) in Uganda and (Holtland, 2007) in Tanzania reported that zero grazing was more economically and environmentally viable. Staat et al. (2003) complement the profitability of SF in Kenya. Ethiopia has a grand plan to transform its economy into a green economy (FDRE, 2011). A transformation of

3 Full Stall Feeding (FSF) adoption in this paper is defined as the practice of feeding some or all animals in a restricted open homestead land in full year and Seasonal Stall Feeding (SSF) for at least one season of the year. Stall fed cattle are not allowed for free movement unless they are out for watering, ploughing and threshing purpose (Lenaerts, 2013) 
the livestock sector is an important part of this plan which targets to reduce greenhouse gas emissions through increasing livestock productivity. The switch from free grazing (FG) to Stall Feeding (SF) ${ }^{1}$ is an important part of this transition and was introduced since 2005 (Lenaerts, 2013; Klitzing et al., 2014; Benin, 2006) in the study area. A recent study by Klitzing et al. (2014) found that fodder productivity from SF schemes is higher than from FG schemes, leading to overall livestock productivity.

However, its adoption rate remains below its expectation (Lenaerts, 2013; FAO, 2007; Bishu, 2014). A recent survey result by BoARD (2012) evidenced that $43.10 \%$ of the respondents were found to use SF in line with Bishu (2014) whose study revealed that $22.7 \%$ of farmers practiced SF in Tigrai region. Similarly, Benin (2006) indicated that adoption of SF practice is 48\% in Amhara region while De Cao et al. (2013) found that $33 \%$ of the sample farmer exercise zero grazing $(\mathrm{ZG})$ in Harar. While the finding of low levels of adoption is well accepted (Lenaerts, 2013), to our knowledge factors influencing SF adoption decision were neither properly identified nor proper empirical design was followed. This study then investigates the nuts and bolts of achieving such a transition in the highlands of northern Ethiopia.

This study aims to contribute to the understanding of the drivers that determine the adoption and intensity of adoption of SF. Technology adoption has long preoccupied economists concerned with the crop productivity potential in less developed countries (LDCs). Moreover, the general theory on adoption is well developed (Feder et al., 1985; Feder and Umali, 1993). Thus, this study addresses the following research questions: Why some farmers have switched from FG to SF practice while others have not? What are the key determinants that influence farmer's decision to use and intensify SF? Boserup's (1965) seminal work indicated that land constraints cause agricultural intensification. With regard to this, Kruseman et al. (2006) and Pender et al. (2006) found positive effects of land shortage on fertilizer use and labor per hectare in Tigrai region. In line to this, our first hypothesis is to test the Boserupian theory that grazing land shortage leads to more SF adoption and SF adoption is associated with the large closed area.

The recent findings from Gunte (2015) revealed that low adoption of improved forage is caused by farmers' resources scarcity such as labor and farm size. Our hypothesis in line to this is that individuals with more labor and breed cows are likely to adopt SF whereas individuals with more herd size and less crop residue are less likely to adopt SF. We further propose that early exposure to SF and information has a positive effect on farmers' adoption and intensity. In line with Boserupian hypothesis, our finding suggests that grazing land shortage increased SF adoption and number of SF adopting seasons. We also found that factors such as access to information, literacy rate, and availability of labor, the number of breed cows, animal shock and exposure to SF significantly and positively influenced SF adoption and its intensity. However, SF appears to be less attractive to those farmers with more herd-size and less crop residue, particularly to those that are with a longer distance to animal water and crop-residue sites. 


\section{Background and Empirical Review of Improved Cattle Feeding Adoption}

Free grazing is a dominant form of livestock rearing in Ethiopia. Most of the grazing lands are grazed and trampled by livestock year round with no resting. This causes in soil compaction and land degradation and hence low quantity and quality of feed (Nyssen et al., 2007).The expansion of improved feeding has been suggested by policy makers with the objectives of (1) increasing cattle and fodder productivity; (2) halting land degradation, and (3) generating income. SF or ZG have been widely recommended and was practiced in the highlands of Kenya and Tanzania (Gass and Sumberg, 1993) as well as Ethiopia (Lenaerts, 2013; Klitzing et al., 2014; Bishu, 2014) while its pace of coverage was slower-than-anticipated.

The practice of SF in Uganda was found to be economically and ecologically sustainable (Garcia et al., 2008). A study by Funte et al. (2009) showed that ZG practices are successful in Harar but low in Tigrai and southern regions. De Cao et al. (2013) revealed that ZG is a potentially useful practice against low productivity and limited feed availability. According to Bishu (2014) and Ahmed et al. (2004), SF is believed not only to improve the productivity of animals but also to protect against transmissible diseases; minimize soil erosion, and conserve manure to enrich soils. Benin (2006) who looked at the adoption of SF in Ethiopia indicated that SF is positively influenced by access to credit, a number of breed cows and land distribution.

Similarly, Gebremedhin et al. (2003) and Beshir (2014) showed that household resource endowment, especially land and labor, herd size and distance to road were key factors influencing forage technology adoption in the highlands of Ethiopia while Baltenweck et al. (2007) reported that farming experience and distance to road were significant factors of residue feeding adoption. A recent study of Gunte (2015) forage adopters had more family labor, reside closer to markets and had better access to information compared to non-adopters in Ethiopia.

The finding from Turinawe et al. (2011) in Uganda proved that a number of improved cows had a positive significant relationship with the use of forage technology. Benin (2006) also found that almost 80 percent of the farmers that adopted improved breeds also adopted SF, and multiple regression analysis by Winsten et al. (2000) confirmed that farmers using confinement feeding were more likely to use milk enhancing technologies than using extensive feeding in the USA. This implies that SF performs best when it is complemented by other related technologies and those who have improved cow are likely to adopt SF. Foltz and Lang (2003) in the study of rotational grazing adoption found that rotational grazing adopters have more education and less land holding size in the US.

The positive role of information diffusion about the new technology through media in the adoption of new technologies are also well documented in the literature (Feder and Umali, 1993). Wünscher et al. (2004) noted the adoption rate of improved forage was found to be low, and lack of information about the use hinder adoption in Costa Rica. The social network may also enable farmers to learn about benefits of new practice from their peers, or respond to their peers' experience so that facilitating the adoption of new practice (Conley and Udry, 2010). Transfer income received from the personal social network may facilitate the adoption 
of a new practice by overcoming cash constraints: this possibility has not been considered in the adoption decision with an exception to the work of Hogset (2005) in Kenya.

The effect of wealth depends on the nature of rural market imperfections (Pender and Kerr, 1996).When labor markets are imperfect, households endowed with high family labor are able to meet the high labor demand of SF practice. Similarly, given the missing markets for improved feed, wealthier households endowed with more assets are able to invest more in this practice. Economic theory states that holding other things fixed, a higher price for milk and meat will increase the net return of better farming practice, but higher input prices (e.g. wage rates, feed) would reduce the returns and hence the incentive to use this practice. Finally, Nalunkuuma et al. (2013) estimated adoption of ZG in Kenya and the results obtained revealed that adoption of ZG was positively affected by age, year of schooling, wealth, dependency ratio, the number of cross breed cows and school children.

\section{Theoretical framework}

Integrated crop-livestock production is an important economic activity that promotes and sustains people's livelihoods in developing countries (Herrero et al., 2010; Ryschawy et al., 2012). In mixed crop-livestock farming systems, farmers use crop residue (R) as a key source of livestock feeding due to the expansion of cropland and low productivity of natural pastures (Alkemade et al., 2012). Moreover, labor is important input used for collecting R collection and transportation from the field to the homestead (Jaleta et al., 2013). Yet population pressure increased income and settlement expansion in LD tend to increase the pressure on this farming system. Adopting more resilient, intensive and sustainable mixed crop-livestock production systems seem to be indispensable to cope up with this pressure and attain the rising demand for food, feed at the smallest damage to natural resources (Kassam et al., 2010).

In this section, we try to distinguish between traditional farmers who uses a lower productivity technology and those who adopt improved technology that generates higher payoffs or yields using a theoretical framework which fits into a larger family of Agricultural household model (AHM) developed by Singh, Squire, and Strauss (1986) and later modified by Huffman (1991) that accommodate technology adoption decision. Sub-Saharan Africa's smallholder farming system is characterized by semi-commercial farms that produce multiple crops either for home consumption or market sale using both own and purchased inputs (Muyanga, Jayne, 2014). In Ethiopia, for instance, cattle farming mainly relies on family labor or hired labor, own produce or purchased crop residue, local or cross breed cows and improved feed or traditional feed under imperfect market conditions. This shows that production behavior cannot be analyzed without analyzing the consumption side of the model (de Janvry et al., 1991). Full explanation of the theoretical model is given in the appendix.

\section{Description of the Study Area and Data}

The study is conducted in Tigrai region, the northern part of Ethiopia by randomly selecting 632 sample households. This study used a cross-sectional data from Tigrai Rural Household Survey (TRHS) dataset collected in 2015. TRHS includes a panel 
of five rounds conducted in 1997/98, 2000/01, 2002/03, 2005/06 and 2014/2015. The available panel dataset provides comprehensive household and plot level data. A cross-sectional data for the year 2014/2015 was extracted from the survey for this thesis. Although the survey covered a total sample size of 632 farmers, this study used a sample of 518 livestock owner farmers of which 187 farmers were practicing SF in a full year and the rest 331 were non-adopters. The summary of all variables are presented in Table 1.

Table 1. Descriptive statistics of explanatory variables

\begin{tabular}{|c|c|c|c|c|}
\hline & $\begin{array}{c}\text { (Non- } \\
\text { users }=331)\end{array}$ & (users $=187$ ) & (Diff) & (T-test) \\
\hline VARIABLES & mean1 & Mean2 & $1-2$ & P-value \\
\hline \multicolumn{5}{|l|}{ Explanatory variables } \\
\hline Family size (number) & 5.659 & 6.251 & -0.593 & 0.007 \\
\hline Household head age(years) & 57.66 & 57.27 & 0.394 & 0.774 \\
\hline Distance to road(walking minutes) & 34.38 & 28.27 & 6.111 & 0.050 \\
\hline $\begin{array}{l}\text { Distance to animal water site(walking } \\
\text { minutes) }\end{array}$ & 32.90 & 24.10 & 8.796 & 0.000 \\
\hline $\begin{array}{l}\text { Ratio of total herd size to farm size(TLU/ } \\
\text { hectare) }\end{array}$ & 6.101 & 6.006 & 0.094 & 0.922 \\
\hline Total number of Cows & 1.287 & 1.241 & 0.046 & 0.732 \\
\hline 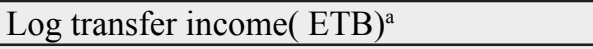 & 7.704 & 7.731 & -0.027 & 0.739 \\
\hline $\begin{array}{l}\text { Labor for rearing cattle per week/farm } \\
\text { size(hr/hectare) }\end{array}$ & 303.6 & 610.1 & -306.5 & 0.000 \\
\hline Feed used per year (donkey load) & 94.60 & 80.44 & 14.16 & 0.009 \\
\hline feed demand per year(donkey load) & 77.88 & 70.57 & 7.314 & 0.074 \\
\hline Distance to grazing land(walking minute) & 54.85 & 62.77 & -7.917 & 0.031 \\
\hline Mean village wage(ETB) & 157.4 & 124.2 & 33.21 & 0.000 \\
\hline Milk price/village wage(ratio) & 0.300 & 0.419 & -0.119 & 0.055 \\
\hline Exposure to SF in years & 3.214 & 4.332 & -1.117 & 0.000 \\
\hline Feed transport time (minutes) & 911.1 & 767.1 & 143.9 & 0.005 \\
\hline $\begin{array}{l}\text { HH farm size relative to Tabia farm } \\
\text { size(hectare) }\end{array}$ & 0.002 & 0.003 & -0.001 & 0.013 \\
\hline $\begin{array}{l}\text { Network- cash assistance from relatives/ } \\
\text { friends (ETB) }\end{array}$ & 1,336 & 1,509 & -172.4 & 0.702 \\
\hline Grazing area to household ratio $\left(\mathrm{Km}^{2}\right)$ & 0.0019 & 0.0013 & 0.001 & 0.041 \\
\hline Average community farm size (hectare) & 1245.8 & 875.9 & 369.8 & 0.000 \\
\hline Closed area to households ratio(hec) & 0.521 & 0.589 & -0.068 & 0.237 \\
\hline HH head sex $($ male $=1)$ & 0.764 & 0.840 & -.0752 & 0.043 \\
\hline HH head Education (literate $=1$ ) & 0.372 & 0.455 & -.0829 & 0.0646 \\
\hline Improved cows $($ breed $=1)$ & 0.0121 & 0.112 & -0.100 & 0.000 \\
\hline Animal shock(shock=1) & 0.157 & 0.283 & -0.126 & 0.001 \\
\hline Farm capital(cart, cattle $\&$ fodder shed=1) & 0.260 & 0.422 & -0.162 & 0.000 \\
\hline Access to formal credit ( yes $=1$ ) & 0.242 & 0.283 & -0.042 & 0.297 \\
\hline
\end{tabular}




\begin{tabular}{|l|c|c|c|c|}
\hline information(TV, radio \& mobile=1) & 0.136 & 0.305 & -0.168 & 0.000 \\
\hline Dependent variables & & & & \\
\hline Full SF adoption (SF in full year round) (0,1) & 63.90 & 36.10 & & \\
\hline $\begin{array}{l}\text { Seasonal adoption (SF at least in one season) } \\
(0,1)\end{array}$ & 44.40 & 55.60 & & \\
\hline Share of cattle under SF in full year(ratio) & ----- & 0.779 & & \\
\hline Share of cattle under SF in season(ratio) & ----- & 0.631 & & \\
\hline & & & & \\
\hline
\end{tabular}

Source: own compilation, 2016: ${ }^{\text {a }}$ cash assistance from relatives/friends plus safety net: 1 \$USD 21 Ethiopian Birr (ETB).

Table 1 showed that the percentage of users and non-users in the full year round were $36.10 \%$ and $63.9 \%$ with a mean intensity ratio of 0.779 . However, farmers practicing SF at least in one season account $55.6 \%$, whereas those non-users were $44.4 \%$ with an intensity ratio of 0.63 . The average grazing area is less than 210 ha per 1839 household heads including the total exclosure area of 685 ha. The average grazing to household ratio is $0.0013 \mathrm{~km}^{2}$ for users compared to $0.0019 \mathrm{~km}^{2}$ for non-users. One $\mathrm{km}^{2}$ grazing land is available for at least 2506 SF users and serves 3289 non-user farmers. The average village farm size is 875.9 ha for users as compared to 1245.8 ha for non-users. The result also indicated that the mean family size of adopting farmers is 6.3 , with an average age of 55.3 years. On average, farmers who adopt SF spend 28.3 and 24 minutes to travel to the nearest road service and animal water site while non-users have more record of walking time. SF users owned a herd size of 6 TLU units with a mean of 1.24 milking cows while those non-users of SF owned about 6.1 TLU units with a mean of 1.29 milking cows.

Farmers using SF had higher mean labor time of 610 hours than the non-users with only 303 hours per week. Farmers using SF also spend 62.3 minutes than non-users with only 54.9 minutes per day to reach free grazing land. SF users, on average, get 1509 ETB as transfer income from friends and/or relatives as a proxy for social network compared to mean of 1336 ETB for non -users. Besides, the average crop residue collecting time for SF users was also smaller (767 $\mathrm{min}$ ) than non-users $(911 \mathrm{~min})$. In relation to the exposure, on average SF users had 4.3 years' experience than non-users with 3.2 years. Moreover, the two groups are different by farm size relative to village farm size, showing 0.003 ha for users and 0.002 ha for non-users.

Among male farmers, $76 \%$ are non-adopters and $84 \%$ are adopters. SF users had a significantly higher literacy level (46\%) than that of non-users $(37 \%)$. SF users own breed cows, on average 9 times higher than that of non-users. Adopters of SF seem to have higher mean value (28\%) in terms of animal shock exposure. Moreover, 20\% of the farmers reported to having access to information via radio, $\mathrm{TV}$ or mobile, of which $31 \%$ of them were found to be SF users. 


\section{Econometric Model of Adoption}

In this section, the econometric model for estimating adoption and intensity is specified. Regarding the structure of the adoption model, a vast literature has focused on the adoption of agricultural techniques applying models that fall into static and dynamic categories (Marra et al., 2003). Due to the cross section nature of data we have, we apply the static model as it is more widely used. We partly overcome its disadvantage by taking adoption as a sequential, multi -stage process, as suggested by De Graaff et al. (2010). The model suggested in this literature is a two-stage model consisting of the following stages: (1) the decision to adopt or not, and (2) intensity of adoption.

Adoptions at the farm level indicate farmers' decisions to use a new technology (Feder et al., 1985). In this case, the full year and seasonal SF adoption are quantified using a binary variable (1.0) and intensity of SF by continuous variables such as share of cattle under SF to describe the extent of adoption. Empirically, continuous decisions have been measured in terms of proportion, scale or intensity of use and in some cases, more than one continuous measure is used to reveal important information about the adoption behavior (Smale and Heisey, 1993).

If we are to assume that farmers have objectives other than profit maximization, their choice of adoption for SF is modeled based on the random utility maximization model following McFadden (1981). More precisely, the technical estimation explained in the study of Misra et al. (1993) gives us a general guideline for applying random utility maximization model to estimate the model. Recalling from the theoretical model in section three, the farmer chooses to adopt SF practice if $Y^{*}=\mathrm{E}\left[\left(\mathrm{Q}^{1}\right)\right]-\mathrm{E}\left[\left(\mathrm{Q}^{0}\right)\right]>\mathrm{V}$. $Y^{*}$ is a latent variable for each farmer that defines their propensity to adopt a new practice that can be expressed as:

$$
Y^{*}=X_{i} \beta+\varepsilon_{j i}
$$

$X_{i}$ indicates the vector of regressors, $\beta$ is a vector of parameters to be estimated and is an error term. Then the binary choice is defined by assuming a probability density function and letting the random variable:

$$
\begin{aligned}
& Y_{i}=1 \text { if } X_{i} \beta+\varepsilon_{j i}>t \\
& Y_{i}=0 \text { if } X_{i} \beta+\varepsilon_{j i} \leq t
\end{aligned}
$$

Where: $Y_{i}$ is the probability of the adoption of SF or alternatively, $Y_{i}$ could be a censored variable indicating the intensity of adoption of SF (e.g., share of cattle under SF practice), and $t$ is a threshold level that can take a value of zero. Then, $\beta$ vector was estimated in an asymptotically efficient method maximizing the log-likelihood function based on probit $(0,1)$ model (Shapiro, 1990). Our interest to estimate intensity conditional on the adoption decision dictates us to choose Heckman's two-stage procedure (Smale et al., 1994). Thus, the Heckman's two-stage procedure is specified by: 


$$
\begin{array}{r}
Y_{1 i}=X_{1} \beta_{1}+\varepsilon_{1} \\
Y_{1 i}=1 \text { if } X_{1} \beta_{1}+\varepsilon_{1}>t \\
Y_{1 i}=0 \text { if } X_{1} \beta_{1}+\varepsilon_{1} \leq t \\
Y_{2 i}=X_{2} \beta_{2}+\varepsilon_{2} \text { if } Y_{1 i}=1 \\
\operatorname{Var}\left(\varepsilon_{1}\right)=1, \operatorname{Var}\left(\varepsilon_{2}\right)=\sigma^{2} \text { assuming } \operatorname{corr}\left(\varepsilon_{1}, \varepsilon_{2}\right)=\rho
\end{array}
$$

Depending on the specification, $Y_{2 i}$ in the second equation is observed when $Y_{1 i}$ equal to one, indicating that the second-stage equation uses the subsample of farmers that adopt the $\mathrm{SF}$ technology. Therefore, the second-stage equation, in our case, was estimated using Hackman second stage. Heckman's two stage procedure is suggested, which allows for a probit equation to be estimated using information from the whole sample and the inverse mills ratio computed from fitted values (Hall, 1994). In the second stage, equations were estimated with the calculated inverse mills ratio function from the probit residuals as an exogenous variable not only to guarantee convergence but also to fix the problem of omission in the nonlinear functions of the right-hand side variables. For the sake of comparison, a Poisson model on the number of SF adopting seasons was also used based on Greene(2008) and Long \& Freeses' (2003) method.

\section{Empirical Result}

\section{Adoption of Stall Feeding}

Estimation of the first stage binary probit and count model explained the behavior of SF practice usage and the number of SF adopting seasons by cattle farmers. Variables included in the analysis of the use of SF practices were selected based on the theoretical model developed in section 3. Marginal Effects (ME) and Incident Rate Ratio (IRR) computed for the use decision and a number of SF adopting seasons are presented in Table 2. An identical set of explanatory variables were used for all estimation revealing how these variables vary in terms of direction, magnitude and significance in influencing adoption decision.

The results from the probit model explaining the adoption of SF practice correctly predicted $80 \%$ of the responses (Table 2). The $\chi^{2}$ for the log likelihood test of the hypothesis that the regressors have zero influence on farmers' adoption was significant. Thus, the hypothesis that the variables have no explanatory power was rejected. Results of the Likelihood Ratio test and the Wald test showed that the inclusion of grazing land, farm, and herd size, enclosure, labor, animal water and feed, shock exposure and the number of the breed increased the model fit significantly. This was consistent with the hypothesis that there exists a strong relationship between these variables and the SF adoption.

Econometric findings from Table 2 confirmed that all five groups of variables derived from the theoretical model shape the decision to adopt SF practices. The results show that small grazing land per household induces adoption and intensity of SF. As grazing land decreases by one- square kilometer, adoption of FSF and SSF are increased by $32 \%$ and $91 \%$ whereas the number of SF adopting season increased by about $1.4 \%$. This reflects that 
smaller grazing is associated with the more intensive use of SF; thereby providing more evidence for the Boserupian theory of population-induced intensification. The findings support the Boserup (1965) hypothesis that population pressure motivates farmers to adopt more intensive cattle farming practices, and are consistent with the findings of Kruseman et al.,(2006) and Benin (2006). Besides, the ratio of the exclosure to the total users appear to be positive factors, causing FSF and SSF adoption to increase by about $15 \%$ and adopting seasons by $29 \%$. While the ratio of individual farm size to village farm size did not affect the decision to us SF, the average village farm again supports the result of Benin (2006) who found that households that own less land are more likely to apply modern agricultural inputs and use more labor and oxen.

Results from Column (1-4) of Table 2 showed that results in the SSF indicated that possession of milking cow contributes positively to the use of SSF.

Table 2. First stage Heckman Estimation of full year (FSF) and Seasonal (SSF) Adoption

\begin{tabular}{|c|c|c|c|c|}
\hline & $M E^{b}(1)$ & $\operatorname{ME}(2)$ & Count(3) & $\operatorname{IRR}^{\mathrm{c}}(4)$ \\
\hline VARIABLES & Full & Seasonal & $\begin{array}{l}\text { Seasons of } \\
\text { SF }\end{array}$ & Seasons of SF \\
\hline \multirow[t]{2}{*}{ Closed area to households ratio(hec) } & $0.133 * * *$ & $0.152 * * *$ & $0.256^{* * *}$ & $1.291 * * *$ \\
\hline & $(0.0383)$ & $(0.0443)$ & $(0.0593)$ & $(0.0765)$ \\
\hline \multirow[t]{2}{*}{$\begin{array}{l}\text { HH farm size relative to village farm } \\
\text { size(hectare) }\end{array}$} & 0.278 & -0.857 & -0.336 & -0.336 \\
\hline & $(6.195)$ & $(8.124)$ & $(6.782)$ & $(6.782)$ \\
\hline \multirow[t]{2}{*}{ Grazing area to household ratio( $\mathrm{Km} 2)$} & $-32.22 * *$ & $-90.73 * * *$ & $-98.66 * * *$ & $1.42 \mathrm{e}-4 * * *$ \\
\hline & $(12.85)$ & $(14.64)$ & $(21.78)$ & $(3.09 \mathrm{e}-4)$ \\
\hline \multirow[t]{2}{*}{ Average community farm size (hectare) } & $-8.70 \mathrm{e}-05^{* *}$ & $5.18 \mathrm{e}-06$ & $-0.000205 * * *$ & $0.9997 * * *$ \\
\hline & $(4.23 \mathrm{e}-05)$ & $(4.33 \mathrm{e}-05)$ & $(6.13 \mathrm{e}-05)$ & $(0.0000)$ \\
\hline \multirow[t]{2}{*}{$\begin{array}{l}\text { Network- cash assistance from relatives/ } \\
\text { friends (ETB) }\end{array}$} & $4.38 \mathrm{e}-06$ & $1.44 \mathrm{e}-05^{*}$ & $1.18 \mathrm{e}-05^{*}$ & $1.0000^{*}$ \\
\hline & $(7.13 \mathrm{e}-06)$ & $(8.71 \mathrm{e}-06)$ & $(6.11 \mathrm{e}-06)$ & $(6.11 \mathrm{e}-06)$ \\
\hline \multirow[t]{2}{*}{ information(access to Tv, radio \&mobile=1) } & $0.181 * * *$ & $0.197 * * *$ & $0.333 * * *$ & $1.3947 * * *$ \\
\hline & $(0.0649)$ & $(0.0580)$ & $(0.0790)$ & $(0.1101)$ \\
\hline \multirow[t]{2}{*}{ Total number of milking cows } & -0.0108 & $0.0400^{*}$ & 0.0372 & 1.0379 \\
\hline & $(0.0196)$ & $(0.0219)$ & $(0.0256)$ & $(0.0266)$ \\
\hline \multirow[t]{2}{*}{ Distance to animal water site ( minutes) } & $-0.00537 * * *$ & $-0.00391 * * *$ & $-0.00922 * * *$ & $0.9908^{* * *}$ \\
\hline & $(0.00138)$ & $(0.00137)$ & $(0.00206)$ & $(0.0020)$ \\
\hline \multirow[t]{2}{*}{ Improved cows (breed=1) } & $0.661 * * *$ & $0.323 * * *$ & $0.700 * * *$ & $2.0133 * * *$ \\
\hline & $(0.0636)$ & $(0.0660)$ & $(0.136)$ & $(2.748)$ \\
\hline \multirow[t]{2}{*}{ Exposure to SF in years } & $0.0595 * * *$ & $0.0927 * * *$ & $0.0746 * * *$ & $1.0774 * * *$ \\
\hline & $(0.0188)$ & $(0.0241)$ & $(0.0251)$ & $(0.0270)$ \\
\hline \multirow[t]{2}{*}{ Labor for rearing cattle per week/farm size(hr/ha) } & $0.000111 * * *$ & $7.00 \mathrm{e}-05^{*}$ & $0.000147 * * *$ & $1.0001 * * *$ \\
\hline & $(3.26 \mathrm{e}-05)$ & $(3.57 \mathrm{e}-05)$ & $(4.18 \mathrm{e}-05)$ & $(0.0000)$ \\
\hline \multirow[t]{2}{*}{ Family size (number) } & $0.0238 * *$ & $0.0208 *$ & $0.0397 * *$ & $1.0405 * *$ \\
\hline & $(0.0112)$ & $(0.0122)$ & $(0.0163)$ & $(0.0169)$ \\
\hline Household head age(years) & -0.00117 & $-0.00362 *$ & $-0.00555^{* *}$ & $0.9944 * *$ \\
\hline
\end{tabular}




\begin{tabular}{|c|c|c|c|c|}
\hline & $(0.00182)$ & $(0.00208)$ & $(0.00253)$ & $(0.0025)$ \\
\hline \multirow[t]{2}{*}{ HH head sex $($ male $=1)$} & $0.139 * *$ & 0.105 & 0.194* & $1.2135^{*}$ \\
\hline & $(0.0595)$ & $(0.0784)$ & $(0.101)$ & $(0.1227)$ \\
\hline \multirow[t]{2}{*}{ HH head Education (literate $=1$ ) } & -0.0117 & $0.130 * *$ & $0.126^{*}$ & $1.1341^{*}$ \\
\hline & $(0.0515)$ & $(0.0556)$ & $(0.0721)$ & $(0.0817)$ \\
\hline \multirow[t]{2}{*}{ Access to formal credit ( Yes $=1$ ) } & 0.0176 & $0.109 *$ & $0.143^{*}$ & $1.1538^{*}$ \\
\hline & $(0.0555)$ & $(0.0589)$ & $(0.0773)$ & $(0.0891)$ \\
\hline \multirow[t]{2}{*}{ Log transfer income( ETB) } & $-0.0607 *$ & $-0.133 * * *$ & $-0.148 * * *$ & $0.8628 * * *$ \\
\hline & $(0.0321)$ & $(0.0368)$ & $(0.0455)$ & $(0.0392)$ \\
\hline \multirow[t]{2}{*}{ Ratio of total herd size to farm size(TLU/ha) } & $-0.0111 * *$ & $-0.00863 * * *$ & $-0.0163 * * *$ & $0.9838 * * *$ \\
\hline & $(0.00440)$ & $(0.00329)$ & $(0.00524)$ & $(0.0051)$ \\
\hline \multirow[t]{2}{*}{ Feed transport time (minutes) } & $-8.89 \mathrm{e}-05^{* *}$ & $-0.000139 * * *$ & $-0.000203 * * *$ & $0.9997 * * *$ \\
\hline & $(4.25 \mathrm{e}-05)$ & $(5.07 \mathrm{e}-05)$ & $(6.08 \mathrm{e}-05)$ & $(0.0001)$ \\
\hline \multirow[t]{2}{*}{ feed demand per year(donkey load) } & -0.000242 & $-0.00123^{* *}$ & -0.000913 & 0.9990 \\
\hline & $(0.000543)$ & $(0.000600)$ & $(0.000790)$ & $(0.0007)$ \\
\hline \multirow[t]{2}{*}{ Distance to grazing land(walking minute) } & 0.000738 & $0.00432 * * *$ & $0.00239 * * *$ & $1.0023 * * *$ \\
\hline & $(0.000577)$ & $(0.000889)$ & $(0.000716)$ & $(0.0007)$ \\
\hline \multirow[t]{2}{*}{ Animal shock(shock=1) } & $0.155^{* *}$ & $0.129 * *$ & $0.239 * * *$ & $1.2702 * * *$ \\
\hline & $(0.0623)$ & $(0.0615)$ & $(0.0784)$ & $(0.0995)$ \\
\hline \multirow[t]{2}{*}{ Mean village wage(ETB) } & $-0.000985^{* * *}$ & $-0.000866^{* *}$ & $-0.00315^{* * *}$ & $0.9968 * * *$ \\
\hline & $(0.000379)$ & $(0.000388)$ & $(0.000627)$ & $(0.0006)$ \\
\hline \multirow[t]{2}{*}{ Milk price/village wage(ratio) } & $0.150 * * *$ & $0.829 * * *$ & $0.440 * * *$ & $1.5529 * * *$ \\
\hline & $(0.0497)$ & $(0.132)$ & $(0.0722)$ & $(0.1120)$ \\
\hline \multirow[t]{2}{*}{ Distance to road(walking minutes) } & $-2.30 \mathrm{e}-05$ & -0.000564 & -0.000575 & 0.9994 \\
\hline & $(0.000807)$ & $(0.000904)$ & $(0.00125)$ & $(0.0012)$ \\
\hline \multirow[t]{2}{*}{ Constant } & - & - & $1.869^{* * *}$ & $1.869 * * *$ \\
\hline & - & - & $(0.447)$ & $(0.447)$ \\
\hline Predicted probability & $79.92 \%$ & $82.82 \%$ & - & - \\
\hline Observed probability & .361 & .556 & & \\
\hline $\begin{array}{l}\text { p-values for the joint LR- Test for HH } \\
\text { chrematistics }\end{array}$ & 0.0000 & 0.0000 & & \\
\hline p-values for the joint LR- Test for market factors & 0.0000 & 0.0000 & & \\
\hline p-values for the joint LR- Test for farm capital & 0.0000 & 0.0000 & & \\
\hline Observations & 518 & 518 & 518 & 518 \\
\hline
\end{tabular}

Source: own compilation, 2016: Standard errors in parentheses: $* * * \mathrm{p}<0.01, * * \mathrm{p}<0.05,{ }^{*} \mathrm{p}<0.1$ indicate level of significance at $1 \% .5 \% \& 10 \%$ respectively: ${ }^{b}$ marginal effects for the full year and seasonal adoption, and ${ }^{\mathrm{c}}$ incident rate of ratio from the Poisson regression

However, the number of improved cows had a positive significant relationship with the use of SF practice in both FSF and SSF. This implies that the likelihood to use FSF increases by about $66 \%$ as they acquire one more improved cows which are in line with the findings of Kaaya et al. (2005) and Benin (2006) who found a positive relationship between a number of breed cattle and adoption of SF. 
Household size significantly increased FSF or SSF adoption as well as SF adopting seasons. Male farmers were more likely to participate; the probability of male farmers adopting was $14 \%$ higher than the probability for female farmers in FSF adoption. Our result agreed with the work of (Beshir, 2014; Gunte, 2015)) who found a direct relation between male farmers and forage adoption in Ethiopia. The results of the study conform to the expectations that age is negatively associated with the probability of SSF adoption indicating that younger farmers are more likely to use SF. Shiferaw and Holden (1998) found that there was an inverse relationship between age and soil conservation practice adoption in Ethiopia. This is probably because older farmers are less energetic to manage the activities of SF practice as compared to the more energetic young farmers. Earlier work by Fufa and Hassan (2006) found that age of a farmer reduces the probability of using agricultural technologies.

Education is a significant factor to induce and realize the benefits of a new technology through the ability to acquire information (Musaba, 2010). As anticipated, literacy had a positive significant effect on adoption of SF, implying that educated farmers are about $13 \%$ to use SSF and increase adopting seasons by about $13 \%$ than their illiterate counterpart in line with Gunte (2015) who found out that literacy had a positive and significant influence on the adoption of forage technology. Results further showed that access to credit had a positive impact on the use of SF, increasing SSF adoption by $11 \%$ and SF adopting seasons by $15 \%$. Similar signs are found in the works of (Mugisha et al., 2004; Beshir, 2014) which can be attributed to the fact that some of the investments of inputs need more money.

Transfer income negatively influenced the decision to use FSF and SSF as well as adopting seasons. The possible justification for this result is that transfer income might be used to utilize other inputs such as fertilizer, breed cow, and labor. This is contrary to the findings by Gebremedhin et al. (2003) but consistent with the findings of Beshir (2014), who found that off-farm income negatively affected forage technology adoption. Access to information did have a positive significant effect on the use of SF (18\%) and adopting seasons $(40 \%)$. This is possible where the information is relevant to livestock production in line with the proposition of Feder and Slade (1984) and Gunte (2015) who stated that adopters of improved forages had higher access to a mobile telephone.

Endowments of livestock as an asset may influence the decision to use SF practice through two mechanisms. Ownership of more livestock may discourage SF adoption by increasing the cost of management but at the same time encourage farmers to adopt SF by making cash available from an animal sale to finance this cost. It was expected that herd size relative to farm size has an inverse relationship with adoption, and the result confirms herd size influenced negatively the use of FSF or SSF adoption. This is possible in the study area where farmers with more herd size cannot afford to stall-fed them on the limited homestead grazing land particularly when feed is available on communal lands. Each additional animal is associated with an estimated $1.1 \%$ decrease in the use of FSF or SSF and 1.6\% decrease in adopting seasons in contrast to the result of Beshir (2014) who found a positive relation between forage adoption and herd size. 
Farmers with higher labor supply relative to farm size were more likely to allocate more cattle to SF, suggesting that SF use imposes an additional labor on farmers. A one hour increase in labor supply increased the adoption of FSF and SSF by $0.01 \%$. The positive relationship agrees with Beshir (2014) and Gunte (2015). As a noticeable finding, results further indicated that social network had the expected positive and significant effect on the probability of SF adoption, showing that farmers with more peers are willing to adopt the practice in favor the results of Hogset (2005) in that transfer income was positively related to adoption in Kenya. This is attributed to the fact that access to informal credit minimizes the problem of liquidity constraint for investments.

The negative and significant relation between feed need and use of SF seem to agree with the expectation, suggesting for every additional donkey load feed demand, the probability of using SSF reduces by $0.1 \%$. This implies that crop residues plays a complementary role for SF and used to fill feed gaps during periods of inadequate crop residues (McIntire and Debrah, 1987) and SF improve the utilization of crop residues and straw even in the presence of abundant crop residues. The negative effect of distance to an animal water source and crop residue on the use of SF supported the hypothesis that long distance and the high cost of transport are negatively associated with the use of SF practice and adopting seasons. The estimated coefficients for distance to an animal water source and transport indicated that the probability of SF adoption is reduced by $0.05 \%$ and $0.01 \%$ when traveling time gets longer.

It was also observed that longer distance to free grazing lands positively influenced the likelihood of SSF adoption by $0.4 \%$ and a number of adopting seasons by $0.23 \%$. The proximity of farmers to roads is essential for timely input delivery and output disposal resulting in less transport cost. Contrary to the study of Gebremedhin et al. (2003), the coefficient of distance to roads had the expected negative sign but insignificant. The milk price relative to the labor wage rate was positive and significant. The probability of using SF and number of SF adopting seasons also seem to decrease with the village labor wage rate, thus underscoring the crucial role played by market incentives in SF decisions. Among the formal information diffusion variables, exposure to SF seems to be the most important determinant in decisions regarding SF. Farmers who were exposed to SF earlier are more likely to manage their cattle under SF in a full year. Similarly, farmers who experienced an animal shock in the last four years were found to support SF practice in conformity with the hypothesis and to the result Bezabih and Sarr (2010) who indicated that shocks from rainfall variability positively affected the level of crop diversity.

The hypothesized relationships embodied in the decision-making model developed in section 3 were tested jointly, using a likelihood ratio test for both estimations. The probability values showing the level of significance are presented in Table 2. It was initially sought to test whether market imperfections are important in SF decisions with the null hypothesis that consumption and production decisions are separable. A non-separability may result from output and factor market imperfections. A familiar approach used to test for market failures is that of testing the joint significance of household characteristics (age, gender, education, household size) for both estimations. 
The joint significance test of consumption and production decisions does not support the hypothesis of separability for both estimations. However, the rejection of the null hypothesis does not clearly indicate which market imperfections are important. These results may imply imperfections in the output market or the labor market. The joint significance test of farm capital reveals the importance of household endowments, highlighting the importance of missing markets for inputs used in SF decisions. As Pender and Kerr (1996) demonstrate, factor endowments will have no effect on production decisions when perfect markets exist, Statistical tests suggested that farm capital is more important in explaining variations in SF. Market factors are also highly significant and relevant in explaining variations in farmer decisions of using SF practices.

\section{Extent of Use Stall Feeding Adoption}

The second aspect of the use decision for a technology is the extent of use, share to which the practices are applied, and was estimated using Heckman model to account for the selection bias associated with missing observations for a given sub-sample due to the truncated nature of the dependent variable. The motivation underlying the use of Heckman regression model was dependent on a statistical rejection of the null hypothesis of sample selection bias. The results for the second stage estimation are summarized in Table 3.

The coefficient of lambda is significant and negative, which suggests that the error terms in the selection and outcome equations are negatively correlated indicating that unobserved factors that make adoption more likely tend to be associated with the lower extent of SF.As shown in Table 3, grazing area ratio and distance, total family and herd size significantly negatively influence farmers' extent of SF adoption but labor supply, distance to the animal water source and farm size ratio positively affect the extent of SF adoption. The ratio of individual farm size to village farm size has opposite signs in the selection and outcome equations. A positive effect is observed for the share of animal kept under SF contrasted by a negative and insignificant effect on the use of SF. This is expected since large farm size produces more crop residue and SF is mainly dependent on this feed. Similar results are found in the study of Beshir (2014). We also found that farmers with less grazing land allocate more cattle to SF, again consistent with the hypothesis of Boserup (1965) and her followers (Benin, 2006).

Table 3. Heckman Second Stage Estimation of full (FSFR) and seasonal (SSFR) Stall Feeding Intensity

\begin{tabular}{|l|c|c|}
\hline & (Full - intensity ) & (Seasonal -Intensity ) \\
\hline VARIABLES & Share of cattle under SF & Share of cattle under SF \\
\hline Closed area to households ratio(hec) & -0.0581 & 0.00674 \\
\hline HH farm size relative to village farm size(hectare) & $(0.0411)$ & $(0.0365)$ \\
\hline & $5.212^{*}$ & $6.046^{*}$ \\
\hline Grazing area to household ratio(Km2) & $(3.137)$ & $(3.639)$ \\
\hline & $-29.60^{* *}$ & $-35.07^{* *}$ \\
\hline Network- assistance from relatives/friends (ETB) & $(15.05)$ & $(15.62)$ \\
\hline & $-7.41 \mathrm{e}-07$ & $-7.07 \mathrm{e}-07$ \\
\hline
\end{tabular}




\begin{tabular}{|c|c|c|}
\hline information(access to Tv, radio \&mobile $=1$ ) & $-0.132 * *$ & -0.0441 \\
\hline & $(0.0518)$ & $(0.0438)$ \\
\hline \multirow[t]{2}{*}{ Total number of milking cows } & $-0.0393 * *$ & $-0.0562 * * *$ \\
\hline & 0.00204 & -0.000579 \\
\hline \multirow[t]{2}{*}{ Distance to animal water site ( minutes) } & 0.00204 & -0.000579 \\
\hline & $(0.00148)$ & $(0.000963)$ \\
\hline \multirow[t]{2}{*}{ Improved cows $($ breed $=1)$} & 0.00377 & $0.137 *$ \\
\hline & $(0.0960)$ & $(0.0703)$ \\
\hline \multirow[t]{2}{*}{ Exposure to SF in years } & -0.0117 & 0.0146 \\
\hline & $(0.0193)$ & $(0.0142)$ \\
\hline \multirow[t]{2}{*}{ Labor for rearing cattle per week/farm size(hr/ha) } & $5.62 \mathrm{e}-05^{* *}$ & $8.49 \mathrm{e}-05 * * *$ \\
\hline & $(2.42 \mathrm{e}-05)$ & $(2.59 \mathrm{e}-05)$ \\
\hline \multirow[t]{2}{*}{ Family size (number) } & $-0.0235 * *$ & $-0.0172 * *$ \\
\hline & $(0.00927)$ & $(0.00831)$ \\
\hline \multirow[t]{2}{*}{ Household head age(years) } & 0.00192 & $0.00277^{* *}$ \\
\hline & $(0.00124)$ & $(0.00126)$ \\
\hline \multirow[t]{2}{*}{ HH head sex $($ male $=1)$} & $-0.0936^{*}$ & -0.0762 \\
\hline & $(0.0560)$ & $(0.0488)$ \\
\hline \multirow[t]{2}{*}{ HH head Education (literate $=1$ ) } & 0.0255 & 0.0306 \\
\hline & $(0.0360)$ & $(0.0361)$ \\
\hline \multirow[t]{2}{*}{ Access to formal credit ( Yes $=1$ ) } & 0.0151 & -0.0164 \\
\hline & $(0.0383)$ & $(0.0396)$ \\
\hline \multirow[t]{2}{*}{ Log transfer income( ETB) } & 0.0414 & 0.0227 \\
\hline & $(0.0269)$ & $(0.0243)$ \\
\hline \multirow[t]{2}{*}{ Ratio of total herd size to farm size(TLU/ha) } & $-0.0199 * *$ & $-0.00374 * *$ \\
\hline & $(0.00944)$ & $(0.00190)$ \\
\hline \multirow[t]{2}{*}{ Feed transport time (minutes) } & $-1.14 \mathrm{e}-05$ & $1.02 \mathrm{e}-05$ \\
\hline & $(3.04 \mathrm{e}-05)$ & $(3.02 \mathrm{e}-05)$ \\
\hline \multirow[t]{2}{*}{ feed demand per year(donkey load) } & -0.000106 & -0.000259 \\
\hline & $(0.000405)$ & $(0.000392)$ \\
\hline \multirow[t]{2}{*}{ Distance to grazing land(walking minute) } & $-0.00163 * * *$ & $-0.00139 * * *$ \\
\hline & $(0.000407)$ & $(0.000418)$ \\
\hline \multirow[t]{2}{*}{ Animal shock(shock=1) } & 0.0163 & 0.0289 \\
\hline & $(0.0474)$ & $(0.0414)$ \\
\hline \multirow[t]{2}{*}{ Milk price/ village wage (ratio) } & 0.0712 & 0.0672 \\
\hline & $(0.0568)$ & $(0.0554)$ \\
\hline \multirow[t]{2}{*}{ Distance to road(walking minutes) } & $0.00140 * *$ & 0.000856 \\
\hline & $(0.000705)$ & $(0.000629)$ \\
\hline \multirow[t]{2}{*}{ Mill's Ratio } & $-0.195 * *$ & $-0.175 * * *$ \\
\hline & $(0.0823)$ & $(0.0503)$ \\
\hline \multirow[t]{2}{*}{ Constant } & $0.839 * * *$ & $0.570 * * *$ \\
\hline & $(0.241)$ & $(0.199)$ \\
\hline Observations & 187 & 288 \\
\hline
\end{tabular}

Source: own compilation, 2016 : Standard errors in parentheses: *** $\mathrm{p}<0.01, * * \mathrm{p}<0.05, * \mathrm{p}<0.1$ indicate level of significance at $1 \% .5 \% \& 10 \%$ respectively

The ratio of herd size to farm size has negative effects in both equations consistent with the idea that more herd size discourages SF use and its intensity. In line with the hypothesis made earlier, the ratio of labor time to farm size positively affected the extent of using SF, indicating that each additional labor spent on animal rearing results in more extent of the 
practice. Household size negatively influenced the intensity of using SF, showing that more family members may engage in crop production (Beshir, 2014). Sex of the farm household head was negatively related to the intensity of use of FSF or SSF implying that that male farmers allocate less share of cattle under SF as compared to their female counterparts. The justification for this is that female farmers might have more chance to stay at home than their male counterparts. Beshir (2014) found opposite signs for other forage technology adoption in Ethiopia.

The literacy rate of household head is positive but not important in the extent of use of SF. Farmers with the longer distance to the nearest road allocate a larger share of their cattle to SF. Age of the farm household head was positively related to the extent of SF use, except in full year. The justification for this is that older farmers might have gained knowledge and could be explained by the fact that the practices of SF require investment on information to break the information barrier that impedes them from using the practice. These findings are consistent with the findings of Kaliba et al., (1997), whose results indicate that older farmers were more likely to adopt SF and have larger intensive feed gardens in Tanzania.

The lack of statistical importance of distance to crop residue and animal water site in decisions regarding the extent of use of SF implies that the observed partial use of this practice can be explained by factors other than these variables. Although statistical significance is lacking, estimation results also show that farmers with animal shock also use SF practice more extensively than those that are shock free. The length of time that farmers have traveled to free grazing lands had a negative and significant impact on cattle under SF. The possible explanation for this could be as the number of traveling minutes to FG increases, it is not economical to allocate more animal to SF and few to FG especially in seasons where free grazing is ubiquitous, as farmers respond to labor savings.

\section{Summary and Conclusion}

Farmers' adoption of SF and number of SF adopting seasons were assessed in northern Ethiopia in 2015 using a household survey sponsored by NORHED-CLISNARP using 518 randomly selected sample farmers. The Heckman model of SF was used to estimate both discrete data and the continuous stage to account for the extent of adoption. Moreover, a Poisson regression model was applied to explain the variation in the number of SF adopting seasons. While SF has been assumed feasible and applicable in the region, its adoption rate has remained below its expectation. A research on this area is relevant to the literature. The aim of this study was to understand the driving factors of a full year and seasonal SF adoption by farmers and its intensity by developing a model of technology adoption within the framework of a utility maximizing agricultural household model.

The study results indicate that the choice of and demand for SF depend on a host of factors identified from the theoretical model. All factors were statistically significant in either the use of or extent of SF practices, or both, implying that the model appropriately explains the nature of SF process in Ethiopia. The rejection of the null 
hypothesis of separable production and consumption decisions support the use of the non-separable household model to analyze the production decisions of SF. Our evidence showed that population pressure seems to be a driving force for intensifying SF in all seasons, supporting Boserup's(1965) hypothesis in that less grazing land increased use of SF and adopting seasons. Adoption of SF was also stimulated by the ratio of the closed area probably by shrinking free grazing land and giving extra by-product for animal feed.

The study also shows that SF appears to be attractive to farmers with more milking cows, particularly those that are with improved cows. Wealthier farmers, as measured by the number of herd size, were less likely to adopt and intensify this practice as feeding a large number of cattle increases the cost of its management. The availability of labor is found to be important in determining the use and extent of the practice. While the distance to the animal water site and crop residue reduce the probability to use SF, distance to grazing land, social network and early exposure to SF greatly increased the likelihood of using SF. The significance of education and information confirmed that the awareness level of a farmer influence adoption of SF, suggesting that addressing illiteracy promote adoption. Male farmers were found to practice SF.

Log of transfer income has a negative impact on the use of the practice, as does the total feed demand. Animal shock is significant in influencing the potential for adopting SF. The analysis also reveals that transfer from social networks positively influences decisions regarding the use of SSF. Market-related factors were found to be the most important factors in explaining variations in the use of SF and its extent. While the coefficient of milk price ratio was positive in both the probability and the extent of use of SF, average village wage rate seems to be in the opposite direction causing the probability of SF use to fall during wage rise. While total labor time ratio, farm size ratio and breed cow ownership positively affect the extent of SF adoption, livestock pressure, distance to grazing land and grazing land ratio negatively influences farmers' extent of SF adoption.

The results of the study have at least three important implications. The first is that cattle SF practice appears to be attractive to the more literate but male households. Thus, policies targeting efficient promotion of the practice are recommended to invest in training and substitute the high quantity herd size with less number of improved cattle. The major implication arising from this study is that efforts to encourage the adoption of SF should be directed towards credit provision, water and road service expansion, for those that have adequate family labor. Information diffusion using demonstration center appear to be justifiable to stimulate and nurture the adoption process. Moreover, better coordination is needed to facilitate the production of complementary feeds and the dissemination of information regarding the market price of an animal product. We enquire for a further research that verifies the link between SF and agricultural productivity. 


\section{References}

1. Ahmed, M. A., Ehui, S., Assefa, Y. (2004): Dairy development in Ethiopia, Intl Food Policy Res Inst.

2. Amudavi, D.M., Khan, Z.R., Wanyama, J.M., Midega, C.A.O., Pittchar, J., Hassanali, A., Pickett, J.A. (2009): Evaluation of farmers'field days as a dissemination tool for PushPull technology in Western Kenya, Crop Protection, No. 28, pp. 987-996.

3. Babulo, B., Muys, B., Fredu, N., Tollens, E., Nyssen, J., Deckers, J., Mathijs, E. (2009): The economic contribution of forest resource uses to rural livelihoods in Tigray, Northern Ethiopia, Forest Policy and Economics, No. 11, pp. 109-117.

4. Baltenweck, I., Mubiru, S., Nanyeenya, W., Njoroge, L., Halberg, N., Romney, D., Staal, S. (2007): Dairy Farming in Uganda: Production Efficiency and Soil Management Strategies under Different Farming Systems, ILRI Research Report 1. International Livestock Research Institute, Nairobi, Kenya.

5. Benin, S. (2006): Policies and programs affecting land management practices, input use, and productivity in the highlands of Amhara region Ethiopia, In: Pender, J., Place, F., Ehui, S. (Eds.), Strategies for Sustainable Land Management in the East African Highlands. International Food Policy Research Institute, Washington, DC, pp. 217-256.

6. Beshir, H. (2014): Factors affecting the adoption and intensity of use of improved forages in North East Highlands of Ethiopia, American Journal of Experimental Agriculture, Vol. 4, No. 1, pp. 12-27.

7. Bezabih, M., Sarr, M. (2012): Risk preferences and environmental uncertainty: Implications for crop diversification decisions in Ethiopia, Environmental and Resource Economics, Vol. 53, No. 4, pp. 483-505.

8. BoARD (2012): Effect of Free Grazing on Natural Resource Management, in Tigray Region, Bureau of agriculture Natural resource development protection and utilization core process, Mekelle, Ethiopia.

9. Boserup, E. (1965): Conditions of Agricultural Growth, Aldine Publications, Chicago.

10. FDRE (2011): Ethiopia's Climate-Resilient Green Economy, Green Economy Strategy, Addis Ababa: CRGE

11. Conley, T. G., Udry, C. R. (2010): Learning about a New Technology: Pineapple in Ghana. American Economic Review, Vol. 100, No. 1, pp. 35-69.

12. De Cao, E., van den Berg, M. M., Tile, C. Y., Wondwosen, T. (2013): The effects of zero grazing in Ethiopia, In Proceedings of the CSAE Conference 2013: Economic Development in Africa, pp. 1-15.

13. De Janvry, A., Fafchamps, M., Sadoulet, E. (1991): Peasant Household Behaviour with Missing Markets: Some Paradoxes Explained, The Economic Journal, Vol. 101, Issue, 409, pp. 1400-1417.

14. De Graaff, J., Kessler, A., Olsen, P. (2010): Farm-level adoption of soil and water 
conservation measures and policy implications in Europe, Land Use Policy No. 27, pp. 1-3.

15. Diao, X., Nin-Pratt, A. (2007): Growth options and poverty reduction in Ethiopia —an economy-wide model analysis, Food Policy Vol. 32, No. 2, pp. 205-228.

16. Edmeades, S. (2003): Variety Choice and Attribute Trade-Offs Within the Framework of Agricultural Household Models: The Case of Bananas in Uganda, A Ph.D. Dissertation, North Carolina State University.

17. FAO (Food and Agriculture Organization of the United Nations) (2009): Production yearbook, FAO, Rome, Italy http://faostat.fao.org/default.aspx.

18. Feder, G., Slade, R. (1984): The Acquisition of Information and the Adoption of New Technology, American Journal of Agricultural Economics, Vol. 66, No. 3, pp. 312-320.

19. Feder, G., Just, R., Zilberman, D. (1985): Adoption of agricultural innovations in developing countries: a survey, Economic Development and Cultural Change, Vol. 33, pp. 255-298.

20. Feder, G., Umali, D. (1993): The Adoption of Agricultural Innovations: A Review, Technological Forecasting and Social Change, No. 43, pp. 215-239.

21. Fufa, B. Hassan, R.M. (2006): Determinants of fertilizer use on maize in Eastern Ethiopia: A weighted Endogenous sampling analysis of the extent and intensity of adoption, Agrekon, Vol. 45, No. 1, pp. 38-49.http://dx.doi.org/10.1016/S0169-5150(99)00028-6.

22. Foltz, J., Lang, G. (2003): The adoption and impact of management-intensive rotational grazing (MIRG) on Connecticut dairy farms, Renewable agriculture and food Systems, Vol. 20, No. 4, pp. 261-266.

23. Fuente, S., Negesse, T., Legesse, G. (2009): Feed Resources and Their Management Systems in Ethiopian Highlands: The Case of Umbulo Whaco Watershed In Southern Ethiopia, Tropical and subtropical agroecosystems, Vol. 12, No. 1, pp. 47-56.

24. Gass, G.M., Sumberg J.E. (1993): Intensification of livestock production in Africa: Experience and issues, Draft. Norwich: University of East Anglia.

25. Garcia, O., Balikowa, D., Kiconco, D., Ndambi, A., Hemme, T. (2008): Milk Production in Uganda: Dairy Farming Economics and Development Policy Impacts, IGAD LPI, Working Paper No. 09-08.

26. Gebremedhin, B., Ahmed, M. M., Ehui, S. K. (2003): Determinants of adoption of improved forage technologies in Crop-livestock mixed systems: Evidence from the highlands of Ethiopia.

27. Gebremedhin, B., Hirpa, A., Berhe, K. (2009): Feed marketing in Ethiopia: Results of rapid market appraisal (No. 15). Full text by ILRI.

28. Greene, W.H. (2008): Econometric Analysis, $6^{\text {th }}$ ed., New Jersey: Prentice Hall.

29. Gunte, K. E. (2015): Understanding factors affecting technology adoption in smallholder livestock production systems in Ethiopia: the role o farm resources and the enabling environment (Doctoral dissertation, Wageningen: Wageningen University).

30. Hall, B.H. (1994): Time Series Processor Version 4.3 Reference Manual, TSP 
International, Palo Alto, CA.

31. Hogset, H. (2005): Social Networks and Technology Adoption, Selected Paper, AAEAAnnual Meetings, July 2005 Providence, RI.

32. Holden, S., Shiferaw, B. (2004): Land degradation, drought and food security in a less favored area in the Ethiopian highlands: a bioeconomic model with market imperfections, Agricultural Economics, Vol. 30, No. 1, pp. 31-49.

33. Holtland, G. (2007): The uneasy relationship between science and development, (May).

34. IFAD (2007): Livestock and range lands; livestock feeding, URL http:/www.ifad. org/lrkm/theme/production/feeding.htm.

35. ILRI (International Livestock Research Institute) (2000): Policy for Sustainable Land Management in the Highlands of Ethiopia, May 22-23, 2000. Addis Ababa, Ethiopia. 20p.

36. Isham, J. T. (2000): A model of Technology Adoption with Social Capital, A Ph.D. Dissertation, University of Maryland.

37. Kaaya, H., Bashaasha, B., Mutetikka, D. (2005): Determinants of utilization of artificial insemination (AI) services among Ugandan dairy farmers, African crop science conference proceedings, No. 7, pp. 561-567.

38. Kaliba, A. R., Featherstone, A. M., Norman, D. W. (1997): A stall-feeding management for improved cattle in semi-arid central Tanzania: factors influencing adoption, Agricultural Economics, Vol. 17, No. 2, pp. 133-146.

39. Kirui, O. K., Mirzabaev, A. (2014): Economics of land degradation in Eastern Africa (No. 128), ZEF Working Paper Series.

40. Klitzing, A., Das, A., Bonzi, M., Barro A., Langkamp, U., Dereje, K., Pale, S., Nayak, S., Gupta, A. (2014): Promoting Best Practice in Agriculture: Examples from Burkina Faso, Ethiopia, India and Europe, Deutsche Welthungerhilfe e.V., Friedrich-Ebert-Straße 1, 53173 Bonn.

41. Kruseman, G., Ruben, R., Tesfay, G. (2006): Village stratification for policy analysis: multiple development domains in the Ethiopian highlands of Tigray, In: Pender, J., Place, F., Ehui, S. (Eds.), Strategies for Sustainable Land Management in the East African Highlands. International Food Policy Research Institute, Washington, DC, pp. 81-106.

42. Lal, R., Stewart, B. A. (2010): Food security and soil quality, Advances in soil science.

43. Lenaerts, L. (2013): Insights into Agency and Social Interactions in Natural Resource Management (Doctoral Dissertation, Wageningen University).

44. Long, F. (2003): Regression Models for Categorical Dependent Variables Using Stata, Revised Edition,

45. Marra, M., Pannell, D.J., Abadi Ghadim, A. (2003): The economics of risk, uncertainty, and learning in the adoption of new agricultural technologies: Where are we on 
the learning curve? Agricultural Systems Vol. 75, No. 2-3, pp. 215-234.

46. McFadden, D. (1981): Econometric models of probabilistic choice. In: Minsk, C.F., McFadden, D. (Eds.), Structural Analysis of Discrete Data with Econometric Applications, MIT Press, Cambridge, MA, pp. 198-272.

47. Mcintire, J., Debrah, S. (1987): Forage research in smallholder and pastoral production systems, In: Little, D.A., and Said, A.N. (eds) Proceedings of a workshop held at Ryall's Hotel, Blantyre, Malawi in September 1986. pp. 118-126. [International Livestock Centre for Africa (ILCA): Addis Ababa, Ethiopia].

48. Mekuria, W., Veldkamp, E., Tilahun, M., Olschewski, R. (2011): Economic valuation of land restoration: The case of exclosures established on communal grazing lands in Tigray, Ethiopia, Land Degradation \& Development, Vol. 22, No. 3, pp. 334-344.

49. Misra, S.K., Carley, D.H., Fletcher, S.M. (1993): Factors influencing southern dairy farmer's choice of milk handlers, J. Agric Appl. Econ. 25 (July), pp. 197-207.

50. Mugisha, J., Ngambeki, D. (1994): Marketing System of the Uganda Banana Industry, African Crop Science Conference Proceedings, No. 1, pp. 384-387.

51. Musaba, E.C. (2010): Analysis of factors influencing adoption of cattle management technologies by communal farmers in Northern Namibia, Livestock Research for Rural Development. Volume 22, Article \#104. Retrieved December 12, 2015, from http://www. 1rrd.org/lrrd22/6/musa22104.htm

52. Nalunkuuma, J., Affognon, H., Kingori, S., Salifu, D., Njonge, F. (2013): Adoption of zero grazing and impact on livestock keepers' knowledge of cattle reproductive parameters in Western Kenya, In African Crop Science Conference Proceedings (Vol. 11, pp. 599-604).

53. Negassa, A., Rashid, S., Gebremedhin, B., Kennedy, A. (2012): Chap. 6 "Livestock Production and Marketing" in Food and Agriculture in Ethiopia, Progress and Policy Challenges. Paul Dorosh and Shahidur Rashid Editors. PENN Press.

54. Nyssen, J., Descheemaeker, K., Nigussie Haregeweyn, M. H., Deckers, J., Poesen, J. (2007): Lessons learned from 10years research on soil erosion and soil and water conservation in Tigray, Tigray Livelihood Papers No. 7, Mekelle: Zala-Date Project, Mekelle University, KU Leuven, Relief Society of Tigrai, Africa museum and Tigrai Bureau of Agriculture and Rural Development, 53 p. ISBN 978-90-8826-027-8.

55. Pender, J., Kerr, J. (1996): Determinants of farmer's indigenous soil and water conservation investments in India's semi-arid tropics, EPTD Discussion Paper No. 17. International Food Policy Research Institute, Washington Dc.

56. Pender, J., Place, F., Ehui, S. (2006): Strategies for Sustainable Land Management in the East African Highlands, International Food Policy Research Institute, Washington, DC.

57. Odame, H, Kimenye, L, Kabutha, C, Alemu, D., Oduori, L.H. (2013): Why the low adoption of agricultural technologies in Eastern and Central Africa? ASARECA(Association for Strengthening Agricultural Research in Eastern and Central Africa), Entebbe.

58. Omamo, S.W., Diao, X., Wood, S., Chamberlin, J., You, L., Benin, S., Wood-Sichra, U., Tatwangire, A. (2006): Strategic Priorities for Agricultural Development in East and 
Central Africa, Research Report 150. Washington, DC: International Food Policy Research Institute (IFPRI).

59. Sadoulet, E., De Janvry, A. (1995): Quantitative Development Policy Analysis, The John Hopkins University Press Baltimore and London.

60. Shapiro, D. (1990): Farm size, household size and composition and women contribution in agriculture: evidence from Zaire, J.Dev. Studies 27 (October), 1-21.

61. Shiferaw, B., Holden, S. (1998): Resource Degradation and Adoption of Land Conservation Technologies in the Ethiopian Highlands: A case Study in Andit Tid, North Shewa, Agricultural Economics, No. 18, pp. 233-247.

62. Singh, I., Squire, L., Strauss, J. (1986): Agricultural Household Models. Extension, Applications and Policy, The Johns Hopkins University Press Baltimore, Maryland 21211, USA.

63. Smale, M., Heisey, P. W. (1993): Simultaneous Estimation of Seed and Fertilizer Adoption Decisions: An Application to Hybrid Maize in Malawi, Technological Forecasting and Social Change, No. 43, pp. 35-368.

64. Smale, M., Just, R.E., Leathers, H.D. (1994): Land allocation in HYV adoption models: an investigation of alternative explanations, Am. J. Agric. Econ. 76 (August), pp. 535-547.

65. Staal, S.J., Waithaka, M., Njoroge, L., Mwangi, D.M., Njubi, D., Wokabi, A. (2003): Costs of milk production in Kenya: Estimates from Kiambu, Nakuru and Nyandarua districts, SDP Research and Development, Report No.1Smallholder Dairy (R\&D) Project.

66. Turinawe, A., Mugisha, J., Kabirizibi, J. (2011): Socio-Economic Evaluation of Improved Forage Technologies in Smallholder Dairy Cattle Farming Systems in Uganda, Journal of Agricultural Science, Vol. 4, No. 3, pp. 163-174. http://doi.org/10.5539/jas. $\underline{\mathrm{v} 4 \mathrm{n} 3 \mathrm{p} 163}$

67. US AID (2013): Climate change and natural resource management, Addis Ababa: USAID. Retrieved from http://www.usaid.gov/ethiopia/environment

68. Winston, J. R., Parsons, R.L., Hanson, G.D. (2000): A profitability analysis of dairy feeding systems in the Northeast, Agricultural and resource economics review, No. 29, pp. $220-228$.

69. Wünscher, T., Schultze-Kraft, R., Peters, M., Rivas, L. (2004): Early adoption of the tropical forage legume Arachis Pintoi in Huetar Norte, Costa Rica, Experimental agriculture, No. 40, pp. 257-268.

70. Yesuf, M., Di Falco, S., Deressa, T., Ringler, C., Kohlin, G. (2008): The impact of climate change and adaptation on food production in low-income countries: evidence from the Nile Basin, Ethiopia, Free downloads from IFPRI.

71. Yilma, Z., Guernebleich, E., Sebsibe, A., Fombad, R. (2011): A review of the Ethiopian dairy sector, Addis Ababa, Ethiopia: FAO Sub-Regional Office for Eastern Africa (FAO/SFE) 


\section{Appendix}

Essentially, farmers face different constraints and so choose among technologies in order to maximize their profit. For simplicity, there are two types of farmers in the model, traditional farmers who use a traditional technology such as free grazing or local cow, and those with an improved technology such as access to stall feeding or breed cow. The use of the improved technology requires extra variable cost for feed including transports $(\mathrm{P}+\mathrm{Ss})$ and fixed cost $(D)$ which enhances the productivity of modern farming. By making technology choices, farmers switch from traditional to more modern farming if the payoffs from switching exceed the costs of adopting the new technology. Assuming there is one period with two stages, each farmer independently decides whether to pay the costs and adopt the technology, or remain with the traditional technology. Then in the second stage each farmer determines how much to produce and how much of this output to sell in a market (or to consume domestically).

For simplicity, the household is assumed to derive utility from the consumption of animal products $\left(x^{m}\right)$ such as milk and milk product, meat, manure and drought power; other purchased goods $\left(x^{o}\right)$, and home time $(h)$. Household utility is affected by a vector of exogenous household characteristics $\left(\Lambda_{h}\right)$, such as human capital, age, and household size and village characteristics $\left(\Lambda_{v}\right)$ including rainfall and agro ecology location that condition household consumption decisions.

$$
\operatorname{ma}_{\psi} U\left[x^{m}, x^{o}, h ; \Lambda_{h}, \Lambda_{v}\right]
$$

Where $\Lambda_{h}$ include factors that influence the marginal utilities of the consumption items to reflect his consumption preferences. Maximization of this equation subject to cash income, time and technology constraint gives demand equations for the improved feeding (F) or breed cow and share allocation to these technologies. Households in LDC mainly engages in animal production for home consumption but a surplus may be sold on the market. Variable inputs used in the production of animal $\left(q^{m}\right)$ are mainly labor $(\mathrm{L})$, crop residue from straw and green grass from free grazing $(\mathrm{R})$ and improved feed $(\mathrm{F})$ on the number of animals $(\hat{\mathrm{C}})$ for given farm $\left(\Lambda_{f}\right)$, household $\left(\Lambda_{h}\right)$, and village $\left(\Lambda_{v}\right)$ characteristic. The production output is assumed to be strictly increasing in variable inputs but at a decreasing rate for a given number of animals $(\hat{\mathrm{C}})$, farm characteristics $\left(\Lambda_{f}\right)$.However, farmers may produce this output under two alternative practices: Modern farming $\left(f^{n}\right)$ and traditional farming $\left(f^{f}\right)$.

\section{Modern farming (}

$f^{\text {th }}$ utilizes labor (L), crop residue $\mathrm{R}(S)$ and improved feed $(\mathrm{F})$ such as mixed fodder, residual brew, salt and, bi-products given the number of animals $\left(C^{m}\right)$ allocated to this farm production. The population pressure $(S)$ reduces the availability of $R$ in the farm production by reducing crop and grazing lands (Muyanga, Jayne, 2014) so that the population pressure $(S)$ should be incorporated into the production technology implicitly, not as a shifter of the production function. Feed production $R$ and its use is driven by rise in population and income, which increase demand for animal product 
and thus the demand for feeds (FAO, 2012b). $f^{m}$ is assumed to be superior to that of $f^{t}$, however, requires additional resources such as cash income to hire labor or buy and transport the extra feed and construct shelter which causes the farmer to incur some variable and fixed costs (in terms of time or money). Farm output under $\left(f^{m}\right)$ may be defined as:

$$
q^{m}=f^{m}\left(C^{m}, \mathrm{~L}, R(S), \mathrm{F} ; \Lambda_{f}, \Lambda_{h}, \Lambda_{v}\right)
$$

\section{Traditional farming $\left(f^{t}\right)$}

Unlike the modern farming, the traditional farmer under $f^{\imath}$ uses only labor (L), crop residue $\mathrm{R}(S)$ given the number of animals $\left(\mathrm{C}^{\mathrm{t}}\right)$ allocated to this farm production but does not depend on the improved feed $(F)$. Its equation looks like:

$$
q^{t}=f^{t}\left(C^{t}, \mathrm{~L}, R(S) ; \Lambda_{f}, \Lambda_{h}, \Lambda_{v}\right)
$$

\section{Total Farming}

The household can choose to manage its production farming with $\left(f^{m}\right)$ or with $\left(f^{t}\right)$ since the two technologies compete for the same number of animals $\left(C^{m}+C^{t}=\right.$ $\bar{C}$ ) or the farmer has an option to allocate some number of animals to $f^{m}$ and the remainder of them to $f^{t}$. For simplicity, if the share of animals the farmer allocates to the $f^{m}$ is represented by (o) and ranges from 0 to 1 , then it can be equal to 0 when no animal is reared under $f^{m}\left(i . e ., C^{m}=0\right.$ ) and equals 1 when all animals are reared under $f^{m}$ (i.e. $C^{m}=\bar{C}$ ). Given a binding number of animals constraint $(\bar{C})$, the total farm output produced by the farmer is given by

$$
Q^{A}=f^{m}\left(\delta, \mathrm{L}, R(S), \mathrm{F} ; \Lambda_{f}, \Lambda_{h}, \Lambda_{v}\right)+f^{t}\left(1-\delta, \mathrm{L}, R(S) ; \Lambda_{f}, \Lambda_{h}, \Lambda_{v}\right)+\varepsilon_{i}
$$

The inclusion of the random variable, $\varepsilon_{i}$ captures the idea that farm production is subject to exogenous risk factors associated with the uncertainty of weather conditions but farmers are assumed to be risk-neutral with respect to the new technology. Therefore the choice of the farming technology is based on expected output. In LDC, households face a bundle of constraints: in the presence of incomplete markets. Farmers may have an exogenous income $(E)$ obtained from networked relatives or safety net which enables them to overcome the cash constraints that imped the new technology adoption. Thus, the full income constraint to the household is expressed as the market value of the marketed surplus $P^{m}\left(Q^{m}-\right.$ $x^{m}$ ) including the exogenous income $E$ but excluding off farm wage because its value is insignificant. Then, this income is spent on purchasing other goods $\left(x^{o}\right)$ consumed by the household at market prices $\left(P^{\circ}\right)$, inputs (F) at a price of $P_{S}$ with transport cost s $\left(P_{S}+s\right)$ and input $(R)$ at a price of $P_{r}\left(P_{r}\right)$ including fixed cost of shelter construction and other farm tools $(D)$ as well as labor wage $(W)$

$P^{m}\left(Q^{A}-x^{m}\right)+E-P^{o} x^{o}-W L-P_{r} R-\left(P_{s}+s\right) \mathrm{F}-D=0$

The difference between the modern and traditional farming lies on the value of, $\left(P_{S}+s\right) \mathrm{F}+D$ term which is the value of extra feed and fixed cost incurred by the modern farmer. Each household has an initial endowment of time allocated between farm production (L) and leisure $(h)$ that is $\mathrm{T}=\mathrm{L}+h$. Then, the objective of the farm household is to maximize utility from the consumption of goods and leisure subject to the farm production, income, and time constraint, given $\eta, \lambda$ and $\mu$ as the Lagrange multipliers of the income, production and the time constraints:

$$
\begin{aligned}
& \max _{\psi} E\left[x^{m}, x^{o}, h ; \Lambda_{h}, \Lambda_{v}\right], \\
& \text { Where } \psi=\left(x^{m}, x^{o}, h, \mathrm{~L}, R, \mathrm{~F}, \delta\right)
\end{aligned}
$$


subject to

Full income constraint:

$P^{m}\left(Q^{A}-x^{m}\right)+E-P^{o} x^{o}-W L-P_{r} R-\left(P_{s}+s\right) \mathrm{F}-D=0$

Production technology:

$\mathrm{G}\left[f^{m}\left(\delta, \mathrm{L}, R(S), \mathrm{F} ; \Lambda_{f}, \Lambda_{h}, \Lambda_{v}\right)+f^{t}\left(1-\delta, \mathrm{L}, R(S) ; \Lambda_{f}, \Lambda_{h}, \Lambda_{v}\right)+\varepsilon_{i}\right]$

Time constraint: $\mathrm{T}=\mathrm{L}+h$

Non-negativity restriction: $\mathrm{F}, R, \delta, \mathrm{L} \geq 0$

An interior solution is expected on the consumption side. However, the utility derived from the use of the farming technology may vary among households and the corner solution is possible for some households indicating that the first-order necessary conditions are derived based on the assumption that an interior solution will hold for some choices but not for others. For instance, it is assumed that every household will consume animal output, other goods and leisure time. Using Kuhn-Tucker conditions, the derivatives of optimal choices of farming technology are derived as follows:

First-order condition

$x^{m}: \frac{\partial U(\cdot)}{\partial x^{m}}-\eta P^{m}=0$

$x^{o}: \frac{\partial U(\cdot)}{\partial x^{\circ}}-\eta P^{o}=0$

$h: \frac{\partial U(.)}{\partial h}-\mu=0$

$L: \lambda \frac{\partial \mathrm{G}(.)}{\partial L}-\eta W-\mu=0$

$R: \lambda\left(\frac{\partial G(\cdot)}{\partial R} * \frac{\partial R}{\partial S}\right)-\eta P_{r}=0$

$F: \lambda\left(\frac{\partial G(.)}{\partial f^{m}} \frac{\partial f^{m}}{\partial F}\right)-\eta\left(P_{S}+s\right) \leq 0 ; F \geq 0$

$\delta: \lambda\left(\frac{\partial G(.)}{\partial f^{m}} \frac{\partial f^{m}}{\partial \delta}-\frac{\partial G(.)}{\partial f^{t}} \frac{\partial f^{t}}{\partial \delta}\right) \leq 0 ; \delta \geq 0$

$\eta: P^{m}\left(Q^{A}-x^{m}\right)+E-P^{o} x^{o}-W L-P_{r} R-\left(P_{s}+s\right) \mathrm{F}-\mathrm{D}=0$

$\lambda: \mathrm{G}\left[f^{m}\left(\delta, \mathrm{L}, R(S), \mathrm{F} ; \Lambda_{f}, \Lambda_{h}, \Lambda_{v}\right)+f^{t}\left(1-\delta, \mathrm{L}, R(S) ; \Lambda_{f}, \Lambda_{h}, \Lambda_{v}\right)\right]$

$\mu: \mathrm{T}-\mathrm{L}-h=0$

Dividing Equations 11 by 10 gives the marginal rate of substitution between work and leisure which shows a possible solution regarding the choice of labor allocation by the household:

$M R S_{L, h}=\frac{\partial G(\cdot)}{\partial L} / \frac{\partial U(\cdot)}{\partial h}=\frac{\eta W+\mu}{\mu \lambda}=w^{*}$

By equating the rate of technical substitution of labor used in farm production for leisure to the marginal valuation of labor, $(\eta W+\mu / \mu \lambda)$ gives the price $\left(w^{*}\right)$ of labor where $W$ is off farm wage within the village. However, looking into equations (13) and (14), the solution of the optimization problem consists of two related decisions: the decision regarding whether or not to adopt new technology and the decision regarding the extent of animals treated under this technology, given that the optimal solution in equation (13) holds with equality. Thus, the modern input $(F)$ will be used and the household will equate the marginal valuation of this input to production to its price plus transport cost. But, if the cost of input $F$ is greater than its marginal valuation, the household will be unwilling to adopt the input $(F)$ so that the observed demand of the input (F) will be censored at zero and this happens when the optimal solution in (13) holds with inequality, and its first order condition can also be defined as follows:

EP 2017 (64) 3 (919-944) 


$$
\frac{\partial G(.)}{\partial f^{m}} \frac{\partial f^{m}}{\partial F}<\frac{\eta\left(P_{s}+s\right)}{\lambda}=M^{*} ; F=0
$$

The two sequential decisions whether to use input (F) or not and allocate some animals to $f^{m}$ reveal that the optimal solution in equation (14) is conditional on the optimal solution in equation (13). This implies that the optimal solution in (14) holds with inequality when the optimal solution in equation (13) also holds with inequality, thereby no animal will not be allocated to the modern technology, indicating that the expected gain from the traditional farming $f^{t}$ exceeds the expected gain derived from the modern technology $f^{m}$, that is

$$
E\left(P^{m} f^{t}\right)>E\left(P^{m} f^{m}+P^{m} f^{t}\right)-M^{*} \mathrm{~F}-\mathrm{D}
$$

This assumes that price of output $\left(P^{m}\right)$ and price of input $\mathrm{F}\left(P_{s}\right)$ may be exogenous for households who participate in the local market. Thus, the optimal share allocated to $\left(f^{m}\right)$ is determined by equating the marginal net benefit in both farming technologies. Depending on the first-order conditions, demand equations for the modern feed $(\mathrm{F})$ and share allocation $(\delta)$ to the modern farming are given as follows:

$F^{*}=F\left(P^{m}, P_{s}, P_{r}, W, S, \mathrm{D}, \Lambda_{f}, \Lambda_{h}, \Lambda_{v}\right)$

$\delta^{*} \mid F>0=\delta\left(P^{m}, P_{S}, P_{r}, W, S, \mathrm{D}, \Lambda_{f}, \Lambda_{h}, \Lambda_{v}\right)$

From this, we expect that adoption of modern feeding and breed cow is discouraged when the cost of adoption $\left(\left(P_{s}+s\right) F+D\right)$ increases that is, $\frac{\partial f^{m}}{\partial F}<0$ and $\frac{\partial f^{m}}{\partial \delta}=0$, thereby reducing farm output, $\frac{\partial G(.)}{\partial f^{m}}<0$ so that farmers will remain with the traditional free grazing or local cow. We also predict that population pressure leads to adoption of modern feeding and breed when the effect on the crop residue and grazing land is negative that is, $\frac{\partial f^{m}}{\partial S}>0$ when $\frac{\partial R}{\partial S}<0$ 